I'm proudest

of the fact

that when

people

around the

country say

that NIJ is

involved with

something,

everyone

knows it's of

\title{
Thoughts From an NIJ Director
}

high quality

and has

\section{Departing}

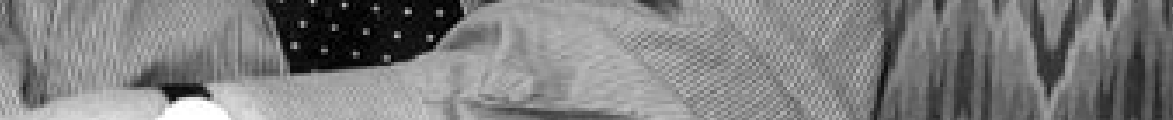




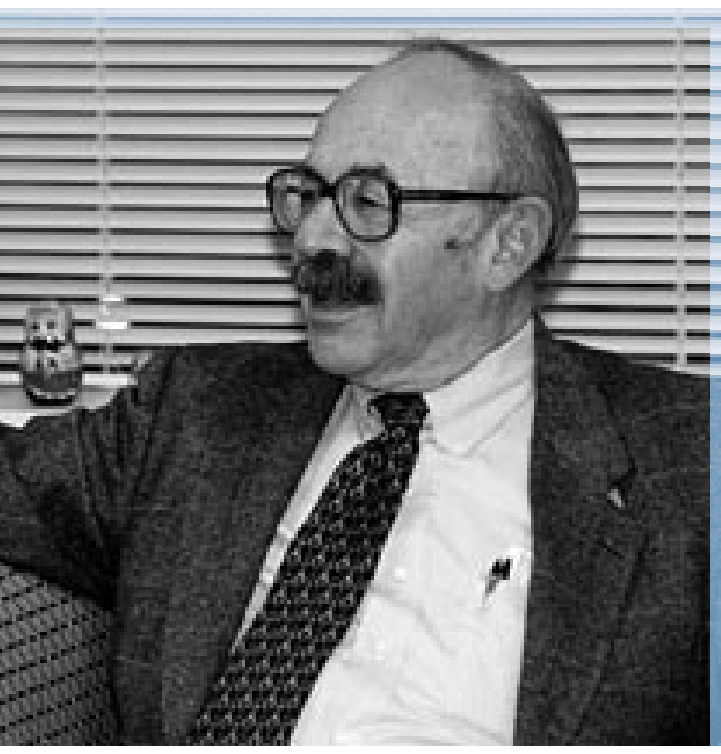

Professor Alfred Blumstein interviews Jeremy Travis on the occasion of Travis' departure from N IJ. Photo: Jim Johnson Photography.

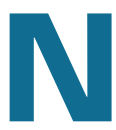
IJ Director Jeremy Travis recently announced that he will be leaving the Institute after $51 / 2$ years to become a Senior Fellow at the U rban Institute in Washington, D.C. On the afternoon of February 18, M r. Travis sat down to discuss his tenure with esteemed criminologist Alfred Blumstein, the J. Erik Jonsson University Professor of U rban Systems and $O$ perations Research at the H. John Heinz III School of Public Policy and $M$ anagement at $C$ arnegie M ellon University. Professor Blumstein is a former dean of the Heinz School and is the Director of the National Consortium on Violence Research. What follows is an excerpt of the conversation between Mr. Travis and Professor Blumstein.

$A B$ : Jeremy, many of us are sorry to learn that you're leaving, after one of the most impressive tenures as NIJ director. I think the world outside is really impressed with what's happened and what's been accomplished. What are you most proud of?

J T: I'm most proud of establishing $\mathrm{NIJ}$ 's place in the world as an organization that's committed to science, committed to independent research activities, and particularly committed to finding relationships that are productive between researchers and practitioners.

$A B$ : I think that's widely recognized as an important accomplishment. What's your sense of how likely that transformation is to continue? What are some of the threats you see to its continuing? And how do we ensure that it will continue?

$\mathrm{J} \mathrm{T}$ : Well, the good news is that at the local level we are seeing new relationships between researchers and practitioners and policymakers that can't be stopped. And those relationships are evolving and becoming a way of doing business that is seen as valuable in itself.

AB: But NIJ did some "pump priming" in this regard...

J T: I think we've played a significant role in accelerating what may have been a naturally occurring phenomenon. We made investments that brought research and police partners together. Then we replicated that in the correctional world, in the violence against women world, and in other areas as well. We've tried to foster a sense of comfort between research and practice so that each has something to teach the other. I think NIJ has played a very valuable role- valuable beyond our dollars- in encouraging different ways of thinking on both sides of the equation.

$A B$ : Different ways of both thinking and organizing...

J T: ... and willingness to reexamine the core ways of doing business.

That momentum cannot be stopped because it is of value to both parties. I also think the funding that's made this possible is very secure, in part because the political situation in this country is such that the Federal government will always now be asked to do something about crime, and we've been successful in asserting the principle that for each Federal crime policy initiative, money should be set aside to conduct research and evaluation.

$A B$ : Is that a principle reflected in statute that is going to continue, or is it subject to change by a change in administration?

J T: The set-aside principle is a principle that is now reflected in statute. Some modifications are now being proposed to make that clearer and establish the level of funding. But the principle is there in statute. So between a Democratic administration and a Republican Congress, this is now seen as the way that we do business. And my hope for the longer term is that we will be able not only to conduct research that is tied to Federal initiatives, but also be able to conduct long-term research projects - that take 5 to 10 years- so we can explore new areas of crime policy on behalf of the country. For example, we have very little research underway on organized crime, on economic crimes, and on emerging issues, such as cybercrime. Those require a long-term research agenda that will help define the research questions, the research methods, and the research opportunities. But we need to be ahead of that curve rather than merely conducting research that is a parallel enterprise to the Federal crime initiatives.

\section{Maintaining}

\section{an Independent}

\section{Research Program}

$A B$ : You mentioned that you're proud of establishing NIJ as an organization that's committed to independent research activities. What insulations are in place to keep the next Attorney General, the next President, and perhaps the next director of NIJ, from tearing down some of the strong protections you've built-up to maintain an independent research program? 
$\mathrm{J} \mathrm{T}$ : The best insulations we have and have had for many years are the two pillars of our statutory authorization, which say, first, that the decision-making authority of the National Institute of Justice is the sole authority of the director. So I have never had to consult with the higher-ups about what grant to award. I've made those decisions within this office. And that's a very important principle, it's a very important legal protection, and it's a very important statement Congress has made [to ensure] an independent research program within the Department of Justice.

\section{A second insulation is the final decision-making authority the $\mathrm{NIJ}$ director has to publish. Our publi- cations are ours alone. They receive the scientific protections of peer review and editing to make sure that they're accessible to the field, but the final decision to publish is reserved to the NIJ director.}

$A B$ : Now, to the extent that a new director is, let's say, an agent of a political Attorney General - that independence is thereby inherently undermined. What happens then?

$\mathrm{J} \mathrm{T}$ : Two things. One is we have built a very strong professional staff that, to their core, believes in these values. Secondly, we've built a strong network outside of the Instituteresearchers and practitioners and policymakers, and members of Congress alike - that believes in these principles.

$A B$ : And that institutional network includes, for example, the National Academy of Sciences Committee on Law and Justice...and what others?

$\mathrm{J} \mathrm{T}$ : I think all the professional associations, the universities, and the high-quality research organizations- they have an interest in the independence of the research product of their faculty and staff. We all have the same interest, which is to ensure that the research process is respected for its independence and its integrity. And to the extent that interest is shared outside of NIJ, our internal ability to advance with independence and integrity is strengthened.

\section{NIJ 's Contribution to Research on Violence, Policing, and Sentencing and Corrections}

$A B$ : We've been talking about some of the organizational issues that have been important, and they really are important. But would you comment on substantive areas that you think have been important developments?

$\mathrm{J} \mathrm{T}$ : Well, I think our research on violence has been a valuable contribution to our understanding and to improving practice- and that's in the areas of family violence, homicides generally, and gun violence. In those three areas, we've made contributions that will help to focus and localize some of the practitioner and policy responses in ways that will improve practice and al ready have. For example, the work we did in Boston with the Boston Gun Project. ${ }^{1}$ That relatively small research grant to Harvard University's J ohn F. Kennedy School of Government has helped us to think about juvenile violence in very innovative, very valuable ways.

Secondly, I think the research portfolio on policing will definea new era of policing. We have done research on organizational change that was never possible before because it's very expensive research. We're asking the question, 'What does it mean to change the culture of an organization toward a new way of doing business?'

$A B$ : Would you say something about those projects?

J T: We've been able to support longitudinal studies of police departments as the unit of analysis in six jurisdictions for, it will be ultimately 6 to 10 years. We're not just studying policing, we're studying the police, we're studying the police

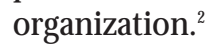

And I think of particular importance has been the growth in our research and policy engagement on the issues of sentencing and corrections. When I came to NIJ in 1994, I was stunned to learn that this research organization was funding very little on what is the major policy challenge of our generation, which is sentencing and corrections.

$A B$ : The whole incarceration issue...

$\mathrm{J}$ T: Right. And so we have funded a very robust research portfolio on those issues, trying to understand the impact of various sentencing options, to look at alternative sentencing policies, to look at prison management.

$A B$ : In that realm, one of the important areas where $\mathrm{NIJ}$ made investments in the past was in crimecontrol theory, with particular emphasis on deterrence and incapacitation. One of the important contributions was, for example, the RAND inmate survey, which investigated individual offending rates or the distribution of lambda. We don't have anything more recent than a survey that was done more than 20 years ago. ${ }^{3}$

J T: I will identify this as a major regret. We wanted to be able to update the lambda estimates, in part because they provide the basis for so much policy debate and discussion and because they have been critiqued by scholars as being inadequate or limited. I think that in the next 5 years, the Institute will be able to mount a major initiative to reestimate the rates of offending.

$A B$ : The crime-control theory program represented the development of an important knowledge base 
that was a step removed from the issues of sentencing and corrections, but it provided an important input to the policy process. The lambda estimates were only a part of that. That level of fundamental researchand it's clearly applied research, but it's not directly applied to practiceshould be an important component of the research agenda for $\mathrm{NIJ}$.

$\mathrm{J} \mathrm{T}$ : We identified this internally as an initiative we wanted to undertake, but with the budget cutback we had this past year particularly, we were not able to even get it started. With the increased funds we've asked for in the 2001 budget and with the greater discretion we've also asked for, this is high on our list.

\section{NIJ 's Growing Budget}

$A B$ : O ne of the characteristics of your administration has been an impressive growth in the gross budget of $\mathrm{NIJ}$. Tell me something about that growth. (See "Sources of NIJ Funds, in Millions, FY 1994-1999.")

J T: The Institute's budget has grown enormously...

\section{$A B$ : From what to what?}

J T: ...when I arrived it was about \$24 million a year. The President's budget for 2001 requests over $\$ 200$ million. That growth has come in a number of areas and through a number of funding mechanisms. And the growth, importantly, has been for a variety of scientific efforts and, increasingly, in the physical sciences and forensic sciences. Some of our most exciting work is about the DNA issue and technology developments that are very important to the field. ${ }^{4}$

\section{AB: What portion of the $\$ 200$ million goes into that?}

\section{J T: Next year it'll be over half.}

$A B$ : So it's over $\$ 100$ million.

J T: Right. It's $\$ 125$ million. So the growth in the Institute's budget has,

Sources of NIJ Funds, in Millions, FY 1994-1999

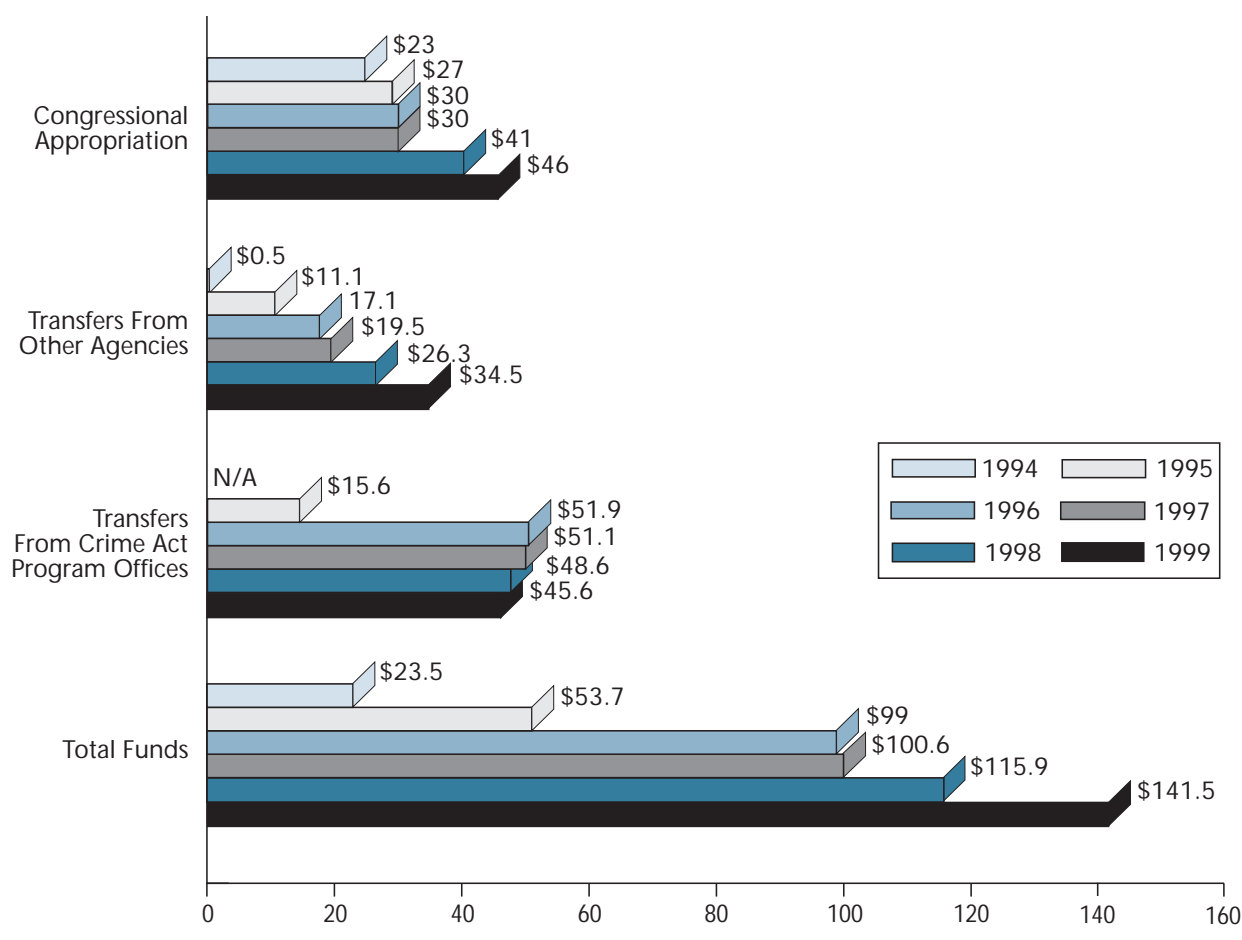

Source: Building Knowledge about Crime and J ustice, The 2000 Research Prospectus of the National Institute of J ustice, November 1999, NCJ 178903.

in part, tracked the needs of the field. The work that we've done in the violence against women area, for example-there's clearly a strong consensus within the country that we need to pay more attention to the phenomenon of family violence. That national interest has made one small area of our portfolio increase by about 10 times.

Some of the growth has been by virtue of our partnerships with our colleague offices within the Department of Justice. So the $\$ 40$ million we've invested in policing research has been by virtue of our partnership with the Office of Community Oriented Policing Services. And that has been important to help inform the changes in policing.

A lot of the growth also is in what I call research infrastructure. For example, the Arrestee Drug Abuse Monitoring (ADAM) program, ${ }^{5}$ which will ultimately grow to a \$20-million-a-year program from a \$2-million-a-year program when I arrived, is an investment in research infrastructure so that we can understand the world of offending at the local level.

Similarly, the development of an international program is a type of infrastructure. It's a way of thinking about research opportunities in the global criminal justice community that we didn't think about 5 years ago.

Another example is the development of our network of technology centers, ${ }^{6}$ which bring science and technology to the field to work on police and other criminal justice issues, to help people think about new technologies that address new and old problems. So infrastructure has been very important, and that's a role that NIJ uniquely can play in helping to advance practice and science. 
Funding for a LongTerm Research Agenda

$A B$ : Even when NIJ's budget was $\$ 25$ million, a lot of that was devoted to infrastructure, like the National Criminal Justice Reference Service. What was the size of the discretionary research program then, and how has that grown or shrunk today?

$\mathrm{J} \mathrm{T}$ : O ur truly discretionary research program, which is that amount of money left over from our ongoing initiatives, and not including the special research programs like that on policing...

$A B$ : ... which have their own discretionary quality because they're targeted...

J T: The decisions are discretionary. But our truly discretionary budget for substantive research is about $\$ 3$ million a year.

$A B$ : It's still as low as $\$ 3$ million a year.

J T: This year, because our budget was reduced, our discretionary budget was reduced, and because we had earmarks against our discretionary budget, this year it will be even less-about $\$ 2$ million.

$A B$ : And that's a ludicrous number in view of the $\$ 100$ to $\$ 200$ billion the Nation spends on crime and justice.

J T: Right. If you were to apply the industry formula and say that we should have a 5-percent research and development budget against that $\$ 100$ billion, we would be able to do a lot more research, and good for the country, I think. But it still has been a time of enormous growth, and other science agencies have also experienced growth. So this has been a good time for science in the Federal sphere, and we have lots of reasons to be very grateful for the support we've gotten. The
President's budget this year, the proposed budget for 2001 , requests a 1-percent setaside of the entire OJP budget to come to $\mathrm{NIJ}$ for research...

$A B$ : ...for discretionary research...

$\mathrm{J} \mathrm{T}$ : Yes, 1 percent of the entire budget of $\$ 4$ billion...

$A B:$...So that would be $\$ 40$ million...

J T: ...\$40 million...for a research budget that is cutting-edge, that is long-term, that addresses issues that are not now within the other funding streams.

$A B$ : Is this a setaside in addition to whatever setasides come in the other streams?

J T: Yes. With a 1-percent setaside, we would be able to tackle things like organized crime, economic crime, estimates of offending, and a list of unmet research priorities. Practitioners and communities want to know about these crime phenomena, but we can't meet their research agenda. A 1-percent setaside would be more than growth. It would give us the ability to define a long-term research agenda. Take, for example, the Project on Human Development in Chicago Neighborhoods. ${ }^{8}$ Because of the ground-breaking work done in that study, we have opportunities to learn a lot more about what happens at the community level. We intend to do some of that kind of investigation through our COM PASS initiative 9 and others. But imagine a world in which we could mount a number of research sites around the country where we were simultaneously asking about informal social control and social capital. We'd be able to look at the variety of experiences that Americans have with crime.

\section{Connecting Research to Practice}

$A B$ : One of the issues that is al ways of concern is the notion that research should generate new insights, new information, new methods that get translated into action. Would you say that NIJ's research has an effective and continuing link to practice?

$\mathrm{J} \mathrm{T}$ : We have a number of stellar examples of initiatives that closely link research and practice.

\section{$A B$ : What are some of those?}

$\mathrm{J} T$ : We have the Breaking the Cycl ${ }^{10}$ initiative, which is testing a hypothesis regarding the impact of a systemwide use of drug treatment and other interventions to reduce drug use. In another demonstration project, we are asking what would happen if judges became involved in managing interventions and sanctions for batterers to try to reduce violence within intimate relationships. ${ }^{11}$

$A B$ : Are these evaluations of ongoing projects?

J T: No. These projects are designed to test research-based hypotheses. That's different from evaluating something that's al ready underway. In these types of approaches, we explicitly set out to use our research knowledge to test a very different way of doing business. The program is designed to yield research findings.

I think the other stellar example of the relationship between research and practice is the effort to apply the lessons learned from the Boston Gun Project-to put researchers and practitioners into very different relationships in which the research partners help define the strategies for intervention in an iterative, ongoing, symbiotic way, hand-inhand with a practitioner team that is trying different approaches. We've now done this in five other cities, and we have different research partners in all of them. ${ }^{12}$

$A B$ : And each city is doing it differently based on its own ideas... 
To place researchers in an environment...

an environment that is in essence a natural laboratory, and give them the ability

to ask questions and get feedback about

behavioral changes from specific interventions,

that is a relationship between research and practice that we've never seen before.

J T: ...own data, own definition of what the crime problem is, their own willingness to collaborate with each other and combine resources. But the researcher is now doing not only analytical work but also is saying, 'Well, let's think about the theoretical implications of trying strategy A versus strategy B.'

$A B$ : And what are some of the theoretical issues that have emerged? I have a sense that there were a number of principles: One, collaboration across the agencies; two, priority setting and communication of those priorities.

\section{$\mathrm{J} T$ : What we're learning from} Boston and its offspring are some very important lessons on deterrence. What are the governmentaland private- actions that have impacts on the behaviors of young people, such that we have some understanding of them in deterrence theory?

$A B$ : What makes that particularly intriguing is that almost all of deterrence research has focused on some aggregate measures of sanction policy.

$\mathrm{J} \mathrm{T}$ : Exactly. And in Boston and its offspring, we are saying that to deter Johnny from engaging in criminal behavior, you have to speak to
Johnny about his behavior. You have to speak to his peer group. You have to speak to his mother.

$A B$ : It demonstrates a necessity to communicate salient messages that are much closer to the audience whose behavior you're trying to change, as opposed to enacting new legislation, for example.

$\mathrm{J} \mathrm{T}$ : The flip side of this is that we are also asking the very important question, 'W hat is the least we have to do to achieve the highest deterrent yield?' Because there's also the risk that, in terms of enforcement or controlling of behavior, we do more than is necessary to get the desired outcome.

$A B$ : Not only the least we have to do, but what is the optimum we have to do. In many cases, if we try to do more than that, we come out being counterproductive because we're diminishing the saliency of the message.

$\mathrm{J} \mathrm{T}$ : To place a researcher in an environment like that, an environment that is in essence a natural laboratory, and give the researchers the ability to ask questions and get feedback about behavioral changes from specific interventions, that is a relationship between research and practice that we've never seen before.
The Impact of Research on Drug Policy

$A B$ : Drug treatment is another area where research has made a major impact on policy and practice. Could you say something about that? Is it in part through drug courts?

J T: In part. But I think it's broader than that. I think NIJ also is making contributions to the national discussion about drug policy because we are able to describe drug use and drug markets and drug users in ways that we couldn't before.

$A B$ : Predominantly through ADAM ...

J T: ...predominantly through ADAM . I think that's our signature contribution. But secondly, we have been able to test drug interventions in ways that have significant implications for policy. Particularly in the area of drug courts, but also in the areas of in-prison drug treatment and postrelease drug testing and treatment. We are looking at the efficacy of a mix of sanctionsimprisonment, testing, treatment, family support-the relationship between carrots and sticks and how they can be finely calibrated to change behavior.

$A B$ : Carrots and sticks in the sense of support and threats.

J T: Right. The behaviors we want to change are both drug-using behavior and other antisocial behaviors. Half to three-quarters of the criminal justice population has a history of drug use. Given the nexus between drug use and the criminal justice population, NIJ's contribution of a solid research base on how criminal justice involvement can be used to reduce drug usethrough drug courts or some sort of judicial intervention involving drug treatment- that's a real accomplishment. 
$A B$ : You mentioned the regret about being unable to update the RAND study. Are there other things you didn't accomplish that you wish you had?

J T: When I leave a job...there's always a short list... There are so many things I hope get carried outCOM PASS, reentry courts, ${ }^{13}$ the 1-percent setaside, the international program. They are not yet done, but I think they're pretty strong seedlings. I wish we had made our argument earlier about the need for a 1-percent setaside for a long-term research agenda in areas not covered by our other setasides. And I wish I could be here after OJP is reorganized $^{14}$ (something I hope will happen) because I think the relationship between the research function and the program development function in OJP will be even stronger.

\section{A Future at the Urban Institute}

AB: You're now off to a program at the Urban Institute. Could you tell us something about your plans there and what issues you expect to pursue at the Urban Institute?

J T: Well, I'm very fortunate to be joining a research organization with a wonderful, rich tradition and history that is interested in asking me to help them build their research program on crime and justice issues and to increase the policy engagement on those issues. And so, in some ways, I'll be continuing to think about things that I care about passionately in a different setting.

My personal agenda is to focus thinking on the issues of crime and justice when seen in the community context. I'm really committed to looking at these as being localized issues where a number of policymakers and community groups and agencies of the criminal justice system have roles to play in produc- ing communities that are safer and more just. I think the Urban Institute, because of its work on those issues in urban settings, with its family focus, education focus, and welfare policy focus, is a place where I can do that.

\section{NIJ 's New Public Image}

$A B$ : Which of your accomplishments at NIJ has given you the most personal satisfaction?

J T: I'm proudest of the fact that when people around the country say that NIJ is involved with something, everyone knows it's of high quality and has met high standards.

$A B$ : So it's the standing in the [criminal justice] community, both the practitioner community and the research community.

J T: And the community. The public has an understanding of $\mathrm{NIJ}$ that it didn't have before. The mission and the value of the Institute are the strongest they've ever been. For example, on one day recently, NIJ was on the news because the Attorney General had told Congress that she was asking us to develop a broad agenda on cybercrime to help respond to this new area of crime. And on the same day, a national newspaper was reporting that we were developing a new initiative on managing the reentry of prisoners back to the community to increase the social functioning of those offenders and the overall safety of those communities. That was a great day.

NCJ 181730

\section{Notes}

1. The Boston Gun Project enlisted the community and implemented problem-solving policing to solve the city's juvenile homicide problem. The Project was completed in two phases- an attack on the drug market that supplied guns to youths and an outreach program for area gangs to set standards for acceptable behavior. If these standards were violated, community police and prosecutors took every available legal action against the offender. See Kennedy, David, "Pulling Levers: Getting Deterrence Right," NIJ Journal (July 1998, JR 000263).

2. The studies are examining policing strategies and organizations in Chicago and Joliet/Aurora, Illinois; Dallas, Texas; Madison, Wisconsin; Tempe, Arizona; and Washington, D.C. Findings will be released in late 2000 .

3. For more information, see Chaiken, Jan M ., and M arcia R. Chaiken, Varieties of Criminal Behavior, Los Angeles: RAND Corporation, August 1982; and Blumstein, Alfred, Jacqueline Cohen, Jeffery A. Roth, and Christy A. Visher, Criminal Careers and "Career Criminals," volume II, Washington, D.C.: N ational Academy Press, 1986.

4. The purpose of the National Commission on the Future of DNA Evidence is to provide the Attorney General with recommendations on the use of current and future DNA methods, applications and technologies in the operation of the criminal justice system, from the crime scene to the courtroom. For more information, visit the Commission's Web page at http://www.ojp.usdoj.gov/dna.

For more information about NIJ's overall technology research and development activities, visit http://www.nlectc.org.

5. The Arrestee Drug Abuse Monitoring (ADAM) program is an NIJ-funded project that tracks drug use trends among booked arrestees in urban areas of the United States. Currently 
operating in 35 sites, ADAM is the only national drug data project using drug testing techniques on arrestees. For more information, visit the program's Web site at http://www.adam-nij.net.

6. The National Law Enforcement and Corrections Technology Centers (NLECTC) are composed of a national center, four regional centers, and four special offices located throughout the country. Their mission is to be a comprehensive source of product and technology information. For more information, visit the program's Web site at http://www.nlectc.org.

7. The Institute's discretionary budget is the portion of the budget that is not already obligated either by Congress through earmarks or by NIJ through its ongoing initiatives.

8. The Project on Human Development in Chicago Neighborhoods began in 1988 with funding from the John D. and Catherine T. MacArthur Foundation, NIJ, the National Institute of M ental Health, the U.S. Department of Education, and the Administration for Children, Youth and Families. It is an interdisciplinary study investigating the factors that contribute to juvenile and adult crime, drug abuse, and violence. To do this, the Project has combined two studies: A thorough examination of Chicago's neighborhoods and a longitudinal study of 6,000 area youth. The researchers are looking at the different circumstances (such as child care and exposure to violence) in each youth's (or child's) life and how these factors affect criminal outcomes. For more information, visit its Web site at http://phden.harvard.edu.

9. Community M apping, Planning, and Analysis for Safety Strategies, or COM PASS, is an NIJ and U.S. Department of Justice initiative to develop and implement a group of crime data systems in select U.S. jurisdictions. Each system will allow better evaluation of the crime problems facing a particular site. It is currently in its developmental stage at a pilot site in Seattle, Washington.

10. Breaking the Cycle is an NIJinitiated program that is testing the hypothesis that arrestee drug testing and mandatory drug abuse treatment, among other interventions, for offenders with histories of drug abuse will decrease future substance abuse and criminal activity. The program currently is in place in three adult and two juvenileU.S. court systems. For more information, see "Building Knowledge About Crime and Justice," National Institute of Justice Research Prospectus, 2000, Washington, D.C.: U.S. Department of Justice, National Institute of Justice, N ovember 1999 (NCJ 178903), pages 6-7, and Harrell, Adele, Foster Cook, and John Carver, "Breaking the Cycle of Drug Abuse in Birmingham," NIJ Journal (July 1998, JR 000236).

11. The Judicial Oversight Demonstration Program is coordinating community responses to domestic violence in three communities by holding offenders accountable through frequent judicial oversight, graduated sanctions, provision of batterer intervention programs, and intensive supervision. The demonstration is jointly funded by the Violence Against Women Office and the N ational Institute of Justice.

12. The Strategic Approaches to Community Safety I nitiative (SACSI) is taking place in five U.S. cities-Indianapolis, Indiana; Memphis, Tennessee; New Haven, Connecticut; Portland, Oregon; and WinstonSalem, North Carolina. The
Initiative's goal is to promote collaborative efforts between researchers and local, State, and Federal crime agencies to help identify and solve community crime problems. This is to be accomplished through crime data retrieval and analysis to inform the design and implementation of strategies to combat, prevent, and reduce crime trends. For more information, see Coleman, Veronica, Walter C. H olton, Jr., Kristine Olson, Stephen C. Robinson, and Judith Stewart, "Using Knowledge and Teamwork to Reduce Crime," N IJ Journal (October 1999, JR 000241).

13. Reentry courts are court systems that manage, through the use of graduated sanctions and positive reinforcement, the release of prisoners into the community. These courts also use additional resources to provide a smoother reentry into society, with the goal that this will lower recidivism rates among offenders. The Office of Justice Programs is managing a demonstration initiative involving reentry in nine States: California, Colorado, Delaware, Florida, Iowa, Kentucky, New York, Ohio, and West Virginia.

14. Congress has asked OJP to reorganize in order to improve service delivery to the criminal justice field. The plan will create subject matter-based program offices, an Office of Grants $M$ anagement/State D esks, and an Information Central Office to provide "one-stop shopping" for information about grants, training, and conferences. A central feature of the reorganization would create a unified research program in NIJ. More information about the restructuring proposal is available from OJP's Office of Congressional and Public Affairs at 202-307-0703. 